\title{
双(3,4,5-取代吡唑基)甲烷衍生物高能量密度材料的分子设计
}

\author{
王厅军*,a,b 李 欢 ${ }^{a}$ 潘仁明 ${ }^{a}$ 朱卫华 ${ }^{a}$ \\ ( ${ }^{a}$ 南京理工大学化工学院 南京 210094) \\ $\left({ }^{b}\right.$ 中国科学院上海有机化学研究所 上海 200032)
}

\begin{abstract}
摘要 设计了一系列双 (3,4,5-取代吡唑基)甲烷衍生物作为高能量密度材料的候选物. 用密度泛函理论研究了它们的生 成热、电子结构、能量特性和热稳定性. 二氟氨基能增加目标化合物的电子结构、密度和爆轰性能的能隙. 其中二 $[3,5-$ 双 (二氟氨基)-4-硝基吡唑]甲烷 $\left(\mathbf{C}_{2}\right)$ 显示了优异的潜在高能量密度材料的性能, 其晶体密度 $\left(2.11 \mathrm{~g} / \mathrm{cm}^{3}\right)$ 、冲击感度 $\left(h_{50}\right.$, $6.8 \mathrm{~J})$ 均高于六硝基六氮杂异伍兹烷(CL-20), 而爆速 $(9.80 \mathrm{~km} / \mathrm{s}$ )和爆压 $(46.62 \mathrm{GPa})$ 与 CL-20 非常接近.

关键词 双(3,4,5-取代吡唑基)甲烷衍生物; 高能量密度材料; 密度泛函理论; 生成热; 爆轰性能; 键解离能
\end{abstract}

\section{Molecular Design of High Energy Density Materials with Bis(3,4,5-substituted-pyrazolyl)methane Derivatives}

\author{
Wang, Wanjun ${ }^{*, a, b} \quad \mathrm{Li}_{1} \operatorname{Huan}^{a} \quad$ Pan, Renming $^{a} \quad$ Zhu, Weihua ${ }^{a}$ \\ $\left({ }^{a}\right.$ School of Chemical Engineering, Nanjing University of Science and Technology, Nanjing 210094) \\ ( ${ }^{b}$ Shanghai Institute of Organic Chemistry, Chinese Academy of Sciences, Shanghai 200032)
}

\begin{abstract}
A series of bis(3,4,5-substituted pyrazolyl)methane derivatives were designed as candidates of high energy density materials (HEDMs). The heats of formation (HOFs), electronic structure, energetic properties and thermal stabilities were studied using density functional theory (DFT) method. The difluoroamino groups could increase energy gaps of electronic structure, density and detonation properties among the title compounds. Bis[3,5-bis(difluoroamino)-4-nitropyrazolyl]methane $\left(\mathbf{C}_{2}\right)$ had excellent properties of potential HEDM. Its crystal density $\left(\rho, 2.11 \mathrm{~g} / \mathrm{cm}^{3}\right)$ and impact sensitivity $\left(h_{50}, 6.8 \mathrm{~J}\right)$ were even higher than those of hexanitrohexaazaisowurtzitane (CL-20), meanwhile its detonation velocity $(D, 9.80 \mathrm{~km} / \mathrm{s})$ and detonation pressure $(P, 46.62 \mathrm{GPa})$ were very close to CL-20.

Keywords bis(3,4,5-substituted pyrazolyl)methane derivatives; high energy density materials; density functional theory; heats of formation; detonation properties; bond dissociation energy
\end{abstract}

\section{Introduction}

High-energy density materials (HEDMs) have attracted considerable attention in recent years. ${ }^{[1-6]} N$-Heterocyclebased energetic materials were promising candidates for HEDMs and had drawn much attention for its high nitrogen content, ${ }^{[7-10]}$ heat of formation (HOF) ${ }^{[11-14]}$ and high density. ${ }^{[13 \sim 18]}$ The synthesis of 3,4,5-trinitro- $1 H$-pyrazole (TNP) ${ }^{[19]}$ provided us a promising HEDM which exhibited favorable stability $\left(T_{\mathrm{dec}}>200^{\circ} \mathrm{C}\right)$, excellent detonation properties $(D=9253 \mathrm{~m} / \mathrm{s}, P=38.6 \mathrm{GPa})$ and good oxygen balance $(+19.69 \%)$. However, the presence of a highly acidic $\mathrm{NH}$ proton $\left(\mathrm{p} K_{\mathrm{a}}=2.35\right)$ affected its practical use as an energetic material, which promoted the developments about structure design and property modification of its derivatives. ${ }^{[20-28]}$ But most attempts only brought about lower oxygen content and energetic performance ${ }^{[29-31]}$ or higher sensitivity. ${ }^{[32]}$

Recently, Fischer et al. ${ }^{[33]}$ had synthesized two secondary explosives (as shown in Figure 1) with the structure of bis(3,4,5-substituted pyrazolyl)methane. Bis(4-amino-3,5dinitropyrazolyl)methane (BADNPM) had a high decomposition temperature at $310{ }^{\circ} \mathrm{C}$ with enhanced detonation parameters in comparison to those of hexanitrostilbene (HNS). Bis(3,4,5-trinitropyrazolyl)methane (BTNPM) had a crystal density of $1.934 \mathrm{~g} / \mathrm{cm}^{3}$. It decomposed at $205{ }^{\circ} \mathrm{C}$, and its experimental impact, friction and electrostatic discharge sensitivity were $4 \mathrm{~J}, 144 \mathrm{~N}$ and $0.1 \mathrm{~J}$, respectively. Its

* Corresponding author. E-mail: wangwj@sioc.ac.cn

Received December 1, 2018; revised February 11, 2019; published online February 19, 2019.

Project supported by the National Natural Science Foundation of China (No. 51603103).

国家自然科学基金(No. 51603103)资助项目. 
theoretical detonation pressure and detonation velocity were $39.1 \mathrm{GPa}$ and $9304 \mathrm{~m} / \mathrm{s}$, respectively. The detonation velocity estimated by the LASEM method was $9910 \mathrm{~m} / \mathrm{s}$, which was approximately equal to that of hexanitrohexaazaisowurtzitane (CL-20). The structure of bispyrazolylmethane provided an efficient approach to avoid the highly acidic NH proton and increase the energetic properties without decrease the stability of TNP. Therefore, the need to do further studies on the molecular design, property prediction and synthesis of bispyrazolylmethane derivatives became so urgent.

Structural modifications could manipulate the properties of most compounds. The optimization of the candidates with high energy and less sensitivity was the primary step for design and synthesis of new energetic materials. ${ }^{[34]} \mathrm{By}$ using theoretical methods based on quantum chemical treatments, structure optimization and property prediction of novel energetic materials could be provided without dangerous and expensive experimental tests. ${ }^{[35,36]}$ In this paper, we reported a systematic study of the heats of formation (HOFs), energetic properties, and thermal stability of a series of bis(3,4,5-substituted pyrazolyl)methane derivatives with different substituents $\left(\mathrm{ONO}_{2}, \mathrm{NO}_{2}, \mathrm{NF}_{2}, \mathrm{~N}_{3}\right.$, $\mathrm{N}\left(\mathrm{NO}_{2}\right) \mathrm{CH}_{3}$ and $\mathrm{NH}_{2}$ ) by using density function theory (DFT).<smiles></smiles><smiles>O=[N+]([O-])c1nn(Cn2c([N+](=O)[O-])c([N+](=O)[O-])c([N+](=O)[O-])c2[N+](=O)[O-])c([N+](=O)[O-])c1[N+](=O)[O-]</smiles>

Figure 1 Structures of bis(4-amino-3,5-dinitropyrazolyl)methane (BADNPM) and bis(3,4,5-trinitropyrazolyl)methane (BTNPM)

\section{Computational methods}

The calculations were performed at B3LYP/6-311G + + $(\mathrm{d}, \mathrm{p})^{[37]}$ and B3PW91/6-31G(d,p $)^{[38]}$ level for different situations by Gaussian 09 package. ${ }^{[39]}$ The optimizations were performed without any symmetry restrictions, using the default convergence criteria in the program. All the optimized structures were characterized to the true local energy minima on the potential surface without imaginary frequencies. The total energy, zero-point energy and thermal correction were calculated with vibration frequencies analysis. Multiwfn program ${ }^{[40]}$ was used to calculate the volume and surface electrostatic potential.

Figure 2 presented the molecular frameworks of a series of bis(3,4,5-substituted pyrazolyl)methane derivatives. On the basis of the 3,5-substituted energetic groups, the compounds could be divided into six series.

Isodesmic reactions could be employed to calculate HOFs using total energies obtained from ab initio calculations. ${ }^{[41,42]}$ Herein, isodesmic reactions were designed in which the numbers of all types of bonds were invariable. Scheme 1 presented the isodesmic reactions used to obtain the HOFs of title compounds and Eq. (1) could be used<smiles>[R]c1nn(Cn2nc([R])c([R])c2[R])c([R])c1[R]</smiles>
A1: $\mathrm{R}^{1}=\mathrm{R}^{2}=\mathrm{ONO}_{2}$
A2: $\mathrm{R}^{1}=\mathrm{ONO}_{2}, \mathrm{R}^{2}=\mathrm{NO}_{2}$
B1: $\mathrm{R}^{1}=\mathrm{NO}_{2}, \mathrm{R}^{2}=\mathrm{ONO}_{2}$
A3: $\mathrm{R}^{1}=\mathrm{ONO}_{2}, \mathrm{R}^{2}=\mathrm{NF}_{2}$
A4: $\mathrm{R}^{1}=\mathrm{ONO}_{2}, \mathrm{R}^{2}=\mathrm{N}_{3}$
A5: $\mathrm{R}^{1}=\mathrm{ONO}_{2}, \mathrm{R}^{2}=\mathrm{N}\left(\mathrm{NO}_{2}\right) \mathrm{CH}_{3}$
A6: $\mathrm{R}^{1}=\mathrm{ONO}_{2}, \mathrm{R}^{2}=\mathrm{NH}_{2}$
B2: $\mathrm{R}^{1}=\mathrm{R}^{2}=\mathrm{NO}_{2}$
B3: $\mathrm{R}^{1}=\mathrm{NO}_{2}, \mathrm{R}^{2}=\mathrm{NF}_{2}$
B4: $R^{1}=\mathrm{NO}_{2}, \mathrm{R}^{2}=\mathrm{N}_{3}$
B5: $R^{1}=\mathrm{NO}_{2}, \mathrm{R}^{2}=\mathrm{N}\left(\mathrm{NO}_{2}\right) \mathrm{CH}_{3}$
C1: $\mathrm{R}^{1}=\mathrm{NF}_{2}, \mathrm{R}^{2}=\mathrm{ONO}_{2}$
B6: $\mathrm{R}^{1}=\mathrm{NO}_{2}, \mathrm{R}^{2}=\mathrm{NH}_{2}$
C2: $\mathrm{R}^{1}=\mathrm{NF}_{2}, \mathrm{R}^{2}=-\mathrm{NO}_{2}$
C3: $R^{1}=R^{2}=N F_{2}$
C4: $R^{1}=\mathrm{NF}_{2}, \mathrm{R}^{2}=\mathrm{N}_{3}$
D1: $R^{1}=\mathrm{N}_{3}, \mathrm{R}^{2}=\mathrm{ONO}_{2}$
D2: $R^{1}=\mathrm{N}_{3}, \mathrm{R}^{2}=\mathrm{NO}_{2}$
D3: $R^{1}=N_{3}, R^{2}=N_{2}$
C5: $\mathrm{R}^{1}=\mathrm{NF}_{2}, \mathrm{R}^{2}=\mathrm{N}\left(\mathrm{NO}_{2}\right) \mathrm{CH}_{3}$
C6: $\mathrm{R}^{1}=\mathrm{NF}_{2}, \mathrm{R}^{2}=\mathrm{NH}_{2}$
D4: $R^{1}=R^{2}=N_{3}$
D5: $\mathrm{R}^{1}=\mathrm{N}_{3}, \mathrm{R}^{2}=\mathrm{N}\left(\mathrm{NO}_{2}\right) \mathrm{CH}_{3}$
D6: $\mathrm{R}^{1}=\mathrm{N}_{3}, \mathrm{R}^{2}=\mathrm{NH}_{2}$
E1: $\mathrm{R}^{1}=\mathrm{N}\left(\mathrm{NO}_{2}\right) \mathrm{CH}_{3}, \mathrm{R}^{2}=\mathrm{ONO}_{2}$
E2: $\mathrm{R}^{1}=\mathrm{N}\left(\mathrm{NO}_{2}\right) \mathrm{CH}_{3}, \mathrm{R}^{2}=\mathrm{NO}_{2}$
E3: $\mathrm{R}^{1}=\mathrm{N}\left(\mathrm{NO}_{2}\right) \mathrm{CH}_{3}, \mathrm{R}^{2}=\mathrm{NF}_{2}$
E4: $\mathrm{R}^{1}=\mathrm{N}\left(\mathrm{NO}_{2}\right) \mathrm{CH}_{3}, \mathrm{R}^{2}=\mathrm{N}_{3}$
E5: $\mathrm{R}^{1}=\mathrm{R}^{2}=\mathrm{N}\left(\mathrm{NO}_{2}\right) \mathrm{CH}_{3}$
E6: $R^{1}=\mathrm{N}\left(\mathrm{NO}_{2}\right) \mathrm{CH}_{3}, \mathrm{R}^{2}=\mathrm{NH}_{2}$
F1: $\mathrm{R}^{1}=\mathrm{NH}_{2}, \mathrm{R}^{2}=\mathrm{ONO}_{2}$
F2: $\mathrm{R}^{1}=\mathrm{NH}_{2}, \mathrm{R}^{2}=\mathrm{NO}_{2}$
F3: $\mathrm{R}^{1}=\mathrm{NH}_{2}, \mathrm{R}^{2}=\mathrm{NF}_{2}$
F4: $\mathrm{R}^{1}=\mathrm{NH}_{2}, \mathrm{R}^{2}=\mathrm{N}_{3}$
F5: $\mathrm{R}^{1}=\mathrm{NH}_{2}, \mathrm{R}^{2}=\mathrm{N}\left(\mathrm{NO}_{2}\right) \mathrm{CH}_{3}$
F6: $R^{1}=R^{2}=\mathrm{NH}_{2}$

Figure 2 Molecular frameworks of bis(3,4,5-substituted pyrazolyl)methane derivatives

to calculate the heats of reactions $\Delta H_{298}$ at $298 \mathrm{~K}$.

$$
\Delta H_{298}=\Delta H_{\mathrm{f}, \mathrm{P}}-\Delta H_{\mathrm{f}, \mathrm{R}}
$$

Where $\Delta H_{\mathrm{f}, \mathrm{P}}$ and $\Delta H_{\mathrm{f}, \mathrm{R}}$ are the HOFs of products and reactants at $298 \mathrm{~K}$, respectively.

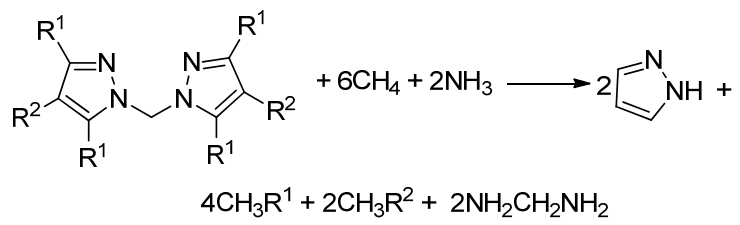

Scheme 1 Isodesmic reaction used to obtain the HOFs of title compounds

The experimental HOFs of reference compounds $\mathrm{CH}_{4}$, $\mathrm{NH}_{3}$, pyrazol, $\mathrm{CH}_{3} \mathrm{ONO}_{2}, \mathrm{CH}_{3} \mathrm{NO}_{2},\left(\mathrm{CH}_{3}\right)_{2} \mathrm{NNO}_{2}$ and $\mathrm{CH}_{3} \mathrm{NH}_{2}$ were available, while the HOFs of $\mathrm{CH}_{3} \mathrm{NF}_{2}$ and $\mathrm{CH}_{3} \mathrm{~N}_{3}$ were calculated by Ju et al. ${ }^{[43,44]}$ As the experimental HOFs of $\mathrm{NH}_{2} \mathrm{CH}_{2} \mathrm{NH}_{2}$ were unavailable, $\mathrm{G}_{2}$ theory ${ }^{[45,46]}$ was used to calculated the accurately value of $\Delta H_{\mathrm{f}}$ by the atomization reaction $\mathrm{C}_{a} \mathrm{H}_{b} \mathrm{~N}_{c} \rightarrow a \mathrm{C}(\mathrm{g})+b \mathrm{H}(\mathrm{g})+c \mathrm{~N}(\mathrm{~g})$. The value of $\Delta H_{298}$ could be also calculated via Eq. (2).

$\Delta H_{298}=\Delta E_{298}+\Delta(P V)=\Delta E_{0}+\Delta E_{\mathrm{ZPE}}+\Delta E_{\mathrm{T}}+\Delta n R T$

Where $\Delta E_{0}$ is the change in total energy between the products and the reactants at $0 \mathrm{~K}, \Delta E_{\mathrm{ZPE}}$ is the difference between the zero-point energies ( $\mathrm{ZPE}$ ) of the the products and the reactants at $0 \mathrm{~K}, \Delta E_{\mathrm{T}}$ is the thermal correction from $0 \mathrm{~K}$ to $298 \mathrm{~K}$. For the isodesmic reaction in this calculation process, $\Delta n=0$, so $\Delta(P V)=0$.

The calculation of detonation properties for most energetic compounds required solid-phase $\operatorname{HOF}\left(\Delta H_{\mathrm{f}, \text { solid }}\right)$ since their condensed phase was solid. According to Hess's low of constant heat summation ${ }^{[47]}$ and Politzer's research ${ }^{[48,49]}$, 
$\Delta H_{\mathrm{f}, \text { solid }}$ could be calculated via Eqs. (3) and (4).

$$
\begin{aligned}
& \Delta H_{\mathrm{f}, \mathrm{solid}}=\Delta H_{\mathrm{f}, \mathrm{gas}}-\Delta H_{\mathrm{sub}} \\
& \Delta H_{\mathrm{sub}}=a A^{2}+b\left(v \sigma_{\mathrm{tot}}^{2}\right)^{0.5}+c
\end{aligned}
$$

Where $\Delta H_{\mathrm{f}, \mathrm{gas}}$ is the gas phase HOF, $\Delta H_{\text {sub }}$ is heat of sublimation, $A$ is the surface area of the 0.001 electrons $/$ bohr $^{3}$ isosurface of the electronic density of the molecule $\left(\mathrm{A}^{2}\right), v$ is the balance of charges between positive potential and negative potential on the isosurface, $v \sigma_{\text {tot }}^{2}$ is a measure of the variability of the electrostatic potential on the molecular surface $\left[(\mathrm{kcal} / \mathrm{mol})^{2}\right]$. The coefficients $a, b$ and $c$ were reported by Rice et al.: $a=2.670 \times 10^{-4} \mathrm{kcal} /\left(\mathrm{mol} \cdot \mathrm{A}^{4}\right), b=$ $1.650 \mathrm{kcal} / \mathrm{mol}$ and $c=2.966 \mathrm{kcal} / \mathrm{mol}^{[50]}$.

Kamlet-Jacobs equations were used to estimate the detonation velocity and pressure ${ }^{[51]}$ [Eqs. (5) and (6)]. And the theoretical density could be obtained from the equation [Eq. (7)] proposed by Polizer et $a l^{[52]}$.

$$
\begin{aligned}
& D=1.01\left(N \bar{M}^{1 / 2} Q^{1 / 2}\right)^{1 / 2}(1+1.30 \rho) \\
& P=1.558 \rho^{2} N \bar{M}^{1 / 2} Q^{1 / 2} \\
& \rho=\alpha\left(\frac{M}{V(0.001)}\right)+\beta v \sigma_{\text {tot }}^{2}+\gamma
\end{aligned}
$$

Terms in Eq. (5) to Eq. (7) are defined as follows: $D$, detonation velocity $(\mathrm{km} / \mathrm{s}) ; P$, detonation pressure $(\mathrm{GPa}) ; N$, moles of detonation gases per gram explosives; $\bar{M}$, average molecular weight of the gases; $Q$, heat of detonation $(\mathrm{J} / \mathrm{g}) ; \rho$, loaded density of explosives $\left(\mathrm{g} / \mathrm{cm}^{3}\right) ; M$, molecular mass $(\mathrm{g} / \mathrm{mol}) ; V(0.001)$, volume of the 0.001 electros $/ \mathrm{bohr}^{3}$ contour of electronic density of the molecule $\left(\mathrm{cm}^{3} / \mathrm{mol}\right)$. The values of $\alpha, \beta$ and $\gamma$ in Eq. (7) are $0.9183,0.0028$ and 0.0443 , respectively.

The impact sensitivity $\left(h_{50}, \mathrm{~cm}\right)$ was defined as the height from which there is a $50 \%$ probability of causing an explosion. Impact sensitivity is generally reported either as the height in $\mathrm{cm}$, designated $h_{50}$, or as the corresponding impact energy in J. With a $2.5 \mathrm{~kg}$ mass, an $h_{50}$ of $1 \mathrm{~cm}$ is equivalent to an impact energy of $0.245 \mathrm{~J}$. The greater the value of $h_{50}$ or the impact energy, the less is the sensitivity. Eq. (8) presented a simple method to estimate the $h_{50}$ of energetic compounds. $^{[53]}$

$$
h_{50}=\alpha \sigma_{+}^{2}+\beta v+\gamma
$$

Where $\sigma_{+}^{2}$ is the strengths and variabilities of the positive surface potentials, $v$ is the degree of balance between the positive and negative potential on a molecular surface. The values of $\alpha, \beta$ and $\gamma$ in Eq. (8) are $-234.83,-3.197$ and 962.0 , respectively.

The bond dissociation energy (BDE) could reflect the strength of bonding, which is fundamental to understand chemical processes. ${ }^{[54]}$ The BDE and BDE with ZPE correction of reaction $\mathrm{A}-\mathrm{B}(\mathrm{g}) \rightarrow \mathrm{A} \bullet(\mathrm{g})+\mathrm{B} \bullet(\mathrm{g})$ at $298 \mathrm{~K}$ and 101 $\mathrm{kPa}$ were given in terms of Eqs. (9) and (10). ${ }^{[55,56]}$

$$
\begin{aligned}
& \mathrm{BDE}_{0}(\mathrm{~A}-\mathrm{B})=E_{0}(\mathrm{~A} \bullet)+E_{0}(\mathrm{~B} \bullet)-E_{0}(\mathrm{~A}-\mathrm{B}) \\
& \mathrm{BDE}(\mathrm{A}-\mathrm{B})_{\mathrm{ZPE}}=\mathrm{BDE}_{0}(\mathrm{~A}-\mathrm{B})+\Delta E_{\mathrm{ZPE}}
\end{aligned}
$$

Where $\Delta E_{\mathrm{ZPE}}$ is the difference between the ZPEs of the products and the reactions.

\section{Result and discussion}

\subsection{Heats of formation}

Table 1 presented the calculated total energy $\left(E_{0}\right)$, zero-point energies $(\mathrm{ZPE})$, thermal corrections $\left(H_{\mathrm{T}}\right)$ and heat of formation (HOF) of the reference compounds in the isodesmic reactions at $\mathrm{B} 3 \mathrm{LYP} / 6-311++\mathrm{G}(\mathrm{d}, \mathrm{p})$ level. Table 2 showed the calculated $E_{0}$, ZPE, $H_{\mathrm{T}}$, molecular properties, heat of sublimation and HOFs of the title com-

Table 1 Calculated total energy $\left(E_{0}\right)$, zero-point energies (ZPE), thermal corrections $\left(H_{\mathrm{T}}\right)$ and heat of formation (HOFs) of the reference compounds at B3LYP/6-311++G(d,p) level

\begin{tabular}{lcccc}
\hline Compound & $E_{0} /$ a.u. & ZPE ${ }^{a} /$ a.u. & $H_{\mathrm{T}}{ }^{a} /\left(\mathrm{kJ}^{\prime} \cdot \mathrm{mol}^{-1}\right)$ & $\mathrm{HOF} /\left(\mathrm{kJ} \bullet \mathrm{mol}^{-1}\right)$ \\
\hline $\mathrm{CH}_{4}$ & -40.4894 & 0.04365 & 9.61 & $-74.60^{b}$ \\
$\mathrm{NH}_{3}$ & -56.5485 & 0.03357 & 9.62 & $-45.94^{b}$ \\
pyrazole & -226.1950 & 0.06955 & 11.83 & $179.40^{b}$ \\
$\mathrm{CH}_{3} \mathrm{NF}_{2}$ & -294.2638 & 0.04564 & 13.14 & $-115.23^{c}$ \\
$\mathrm{CH}_{3} \mathrm{ONO}_{2}$ & -320.2390 & 0.05292 & 15.00 & $-124.40^{b}$ \\
$\mathrm{CH}_{3} \mathrm{NO}_{2}$ & -245.0420 & 0.04864 & 13.35 & $-74.30^{b}$ \\
$\mathrm{CH}_{3} \mathrm{~N}_{3}$ & -204.1033 & 0.04908 & 13.64 & $296.54^{d}$ \\
$\left(\mathrm{CH}_{3}\right)_{2} \mathrm{NNO}_{2}$ & -339.6683 & 0.09274 & 19.26 & $-0.84^{e}$ \\
$\mathrm{CH}_{3} \mathrm{NHNO}_{2}$ & -300.3781 & 0.06569 & 15.48 & $-12.48^{f}$ \\
$\mathrm{CH}_{3} \mathrm{NH}_{2}$ & -95.8301 & 0.06251 & 11.05 & $-22.50^{b}$ \\
$\mathrm{NH}_{2} \mathrm{CH}_{2} \mathrm{NH}_{2}$ & -151.1839 & 0.08030 & 13.59 & $-4.98^{f}$ \\
\hline
\end{tabular}

${ }^{a}$ The scaling factors for ZPE and $H_{\mathrm{T}}$ were 0.98 and 0.96 , respectively; ${ }^{[57]}{ }^{b}$ Experimental values taken from reference [58]; ${ }^{c}$ Calculated values taken from reference [43]; ${ }^{d}$ Calculated values taken from reference [44]; ${ }^{e}$ Experimental values taken from reference [59]; ${ }^{f}$ Calculated value by G2 theory from the atomization reaction $\mathrm{CH}_{6} \mathrm{~N}_{2} \rightarrow \mathrm{C}(\mathrm{g})+6 \mathrm{H}(\mathrm{g})+2 \mathrm{~N}(\mathrm{~g})$. 
Table 2 Calculated $E_{0}, Z P E, H_{T}$, molecular properties, heat of sublimation and HOFs of the title compounds at B3LYP/6-311++ G(d,p) level

\begin{tabular}{|c|c|c|c|c|c|c|c|c|}
\hline Compd. & $E_{0} /$ a.u. & ZPE/a.u. & $H_{\mathrm{T}} /\left(\mathrm{kJ} \bullet \mathrm{mol}^{-1}\right)$ & $\Delta H_{\mathrm{f}, \mathrm{gas}} /\left(\mathrm{kJ} \bullet \mathrm{mol}^{-1}\right)$ & $A / \mathrm{A}^{2}$ & $v \sigma_{\mathrm{tot}}^{2} /\left(\mathrm{kcal}^{\prime} \cdot \mathrm{mol}^{-1}\right)^{2}$ & $\Delta H_{\mathrm{sub}} /\left(\mathrm{kJ} \cdot \mathrm{mol}^{-1}\right)$ & $\Delta H_{\mathrm{f}, \mathrm{solid}} /\left(\mathrm{kJ} \cdot \mathrm{mol}^{-1}\right)$ \\
\hline $\mathbf{A}_{1}$ & -2169.0157 & 0.1791 & 84.13 & -87.18 & 424.46 & 12.96 & 238.53 & -325.71 \\
\hline $\mathbf{A}_{2}$ & -2018.6122 & 0.1736 & 76.65 & 125.94 & 384.68 & 32.38 & 217.00 & -91.06 \\
\hline $\mathbf{A}_{3}$ & -2117.0472 & 0.1660 & 79.59 & 65.82 & 396.46 & 13.45 & 213.32 & -147.50 \\
\hline $\mathbf{A}_{4}$ & -1936.7647 & 0.1734 & 78.85 & 787.91 & 404.34 & 13.54 & 220.45 & 567.46 \\
\hline $\mathbf{A}_{5}$ & -2207.8787 & 0.2600 & 91.78 & 234.95 & 450.98 & 34.74 & 280.30 & -45.35 \\
\hline $\mathbf{A}_{6}$ & -1720.2454 & 0.1987 & 74.36 & 75.27 & 381.23 & 22.26 & 207.34 & -132.07 \\
\hline $\mathbf{B}_{1}$ & -1868.1698 & 0.1667 & 70.79 & 355.02 & 369.74 & 25.77 & 200.18 & 154.84 \\
\hline $\mathbf{B}_{2}$ & -1717.7397 & 0.1598 & 65.00 & 551.87 & 344.85 & 21.07 & 176.95 & 374.92 \\
\hline $\mathbf{B}_{3}$ & -1816.1807 & 0.1534 & 66.19 & 477.39 & 339.44 & 22.17 & 173.63 & 303.76 \\
\hline $\mathbf{B}_{4}$ & -1635.9118 & 0.1616 & 64.71 & 1165.13 & 352.40 & 31.31 & 189.77 & 975.36 \\
\hline $\mathbf{B}_{5}$ & -1907.0315 & 0.2477 & 78.09 & 596.35 & 399.47 & 30.01 & 228.50 & 367.85 \\
\hline $\mathbf{B}_{6}$ & -1419.4344 & 0.1897 & 56.59 & 346.20 & 312.35 & 33.61 & 161.42 & 184.78 \\
\hline $\mathbf{C}_{1}$ & -2065.0572 & 0.1529 & 75.19 & 191.29 & 371.34 & 10.33 & 188.64 & 2.65 \\
\hline $\mathrm{C}_{2}$ & -1914.6306 & 0.1468 & 68.41 & 380.06 & 340.56 & 28.13 & 178.59 & 201.47 \\
\hline $\mathbf{C}_{3}$ & -2013.0788 & 0.1398 & 70.91 & 286.41 & 343.25 & 8.39 & 164.03 & 122.38 \\
\hline $\mathrm{C}_{4}$ & -1832.8043 & 0.1476 & 69.57 & 987.94 & 357.72 & 14.35 & 181.51 & 806.43 \\
\hline $\mathrm{C}_{5}$ & -2103.9188 & 0.2337 & 83.28 & 433.14 & 410.32 & 35.56 & 241.66 & 191.48 \\
\hline $\mathrm{C}_{6}$ & -1616.2958 & 0.1744 & 63.02 & 248.83 & 318.57 & 21.59 & 157.86 & 90.97 \\
\hline $\mathbf{D}_{1}$ & -1704.5053 & 0.1687 & 73.37 & 1603.34 & 402.93 & 17.89 & 222.98 & 1380.36 \\
\hline $\mathbf{D}_{2}$ & -1554.0978 & 0.1638 & 64.83 & 1743.36 & 363.90 & 39.82 & 203.91 & 1539.45 \\
\hline $\mathbf{D}_{3}$ & -1652.5408 & 0.1560 & 67.98 & 1661.92 & 367.00 & 21.35 & 194.77 & 1467.15 \\
\hline $\mathbf{D}_{4}$ & -1472.2283 & 0.1641 & 67.26 & 2464.62 & 381.76 & 16.94 & 203.63 & 2260.99 \\
\hline$D_{5}$ & -1743.3653 & 0.2505 & 80.14 & 1850.71 & 435.51 & 34.07 & 264.59 & 1586.12 \\
\hline$D_{6}$ & -1255.7022 & 0.1915 & 60.86 & 1773.44 & 347.60 & 31.87 & 186.36 & 1587.08 \\
\hline $\mathbf{E}_{1}$ & -2246.7313 & 0.3417 & 98.22 & 501.15 & 480.68 & 30.70 & 308.78 & 192.37 \\
\hline $\mathbf{E}_{2}$ & -2096.3249 & 0.3356 & 91.55 & 637.00 & 439.98 & 37.91 & 271.17 & 365.83 \\
\hline $\mathbf{E}_{3}$ & -2194.7655 & 0.3281 & 94.10 & 562.05 & 445.14 & 36.38 & 275.41 & 286.64 \\
\hline $\mathbf{E}_{4}$ & -2014.4773 & 0.3365 & 92.86 & 1301.22 & 464.30 & 34.27 & 293.65 & 1007.57 \\
\hline $\mathbf{E}_{5}$ & -2285.5945 & 0.4233 & 104.53 & 739.13 & 486.77 & 33.94 & 317.33 & 421.80 \\
\hline $\mathbf{E}_{6}$ & -1797.9528 & 0.3647 & 84.80 & 606.28 & 409.62 & 37.80 & 242.30 & 363.98 \\
\hline $\mathbf{F}_{1}$ & -1271.4719 & 0.2219 & 61.06 & 167.91 & 324.41 & 41.74 & 174.58 & -6.67 \\
\hline $\mathbf{F}_{2}$ & -1121.0935 & 0.2190 & 50.18 & 234.44 & 284.01 & 57.28 & 154.77 & 79.67 \\
\hline $\mathbf{F}_{3}$ & -1219.5116 & 0.2106 & 54.19 & 217.66 & 288.45 & 32.37 & 144.64 & 73.02 \\
\hline $\mathbf{F}_{4}$ & -1039.1850 & 0.2189 & 53.70 & 1058.14 & 303.47 & 27.76 & 151.66 & 906.48 \\
\hline $\mathbf{F}_{5}$ & -1310.3131 & 0.3047 & 66.55 & 465.98 & 356.54 & 46.93 & 201.71 & 264.27 \\
\hline$F_{6}$ & -822.6494 & 0.2473 & 45.51 & 392.73 & 267.19 & 32.14 & 131.30 & 261.43 \\
\hline
\end{tabular}

pounds. The $D$-serie and $\mathrm{X}_{4}(\mathrm{X}=\mathrm{A}, \mathrm{B}, \mathrm{C}, \mathrm{D}, \mathrm{E}, \mathrm{F})$ had the obvious highest HOFs among the series and the title compounds in each series, respectively. The substitution of azido group enhanced the HOF values of the title compounds extremely. More clear evidences about the effects of the different substituents on $\Delta H_{\mathrm{f} \text {,gas }}$ and $\Delta H_{\mathrm{f} \text {,solid }}$ of the title compounds were presented in Figure 4 . The variation of $\Delta H_{\mathrm{f} \text {,gas }}$ behaved the similar trend with $\Delta H_{\mathrm{f} \text {,solid. }}$ Generally, the azido group was very useful to improve the HOFs of energetic materials.

\subsection{Electronic structure}

Table 3 presented the calculated highest occupied molecular orbital (HOMO), lower unoccupied molecular orbital (LUMO) energies and energy gaps ( $\left.\Delta E_{\mathrm{LUMO}-\mathrm{HOMO}}\right)$ of the title compounds at B3LYP/6-311 + $+\mathrm{G}(\mathrm{d}, \mathrm{p})$ level. Figure 5 showed the effects of different substituents on $\Delta E_{\text {LUMO-номо }}$ of the title compounds. For most series, the substitution of $\mathrm{NF}_{2}$ increased the LUMO-HOMO gaps except for $\mathrm{B}$ serie. This indicated the incorporation of $\mathrm{NF}_{2}$ into 


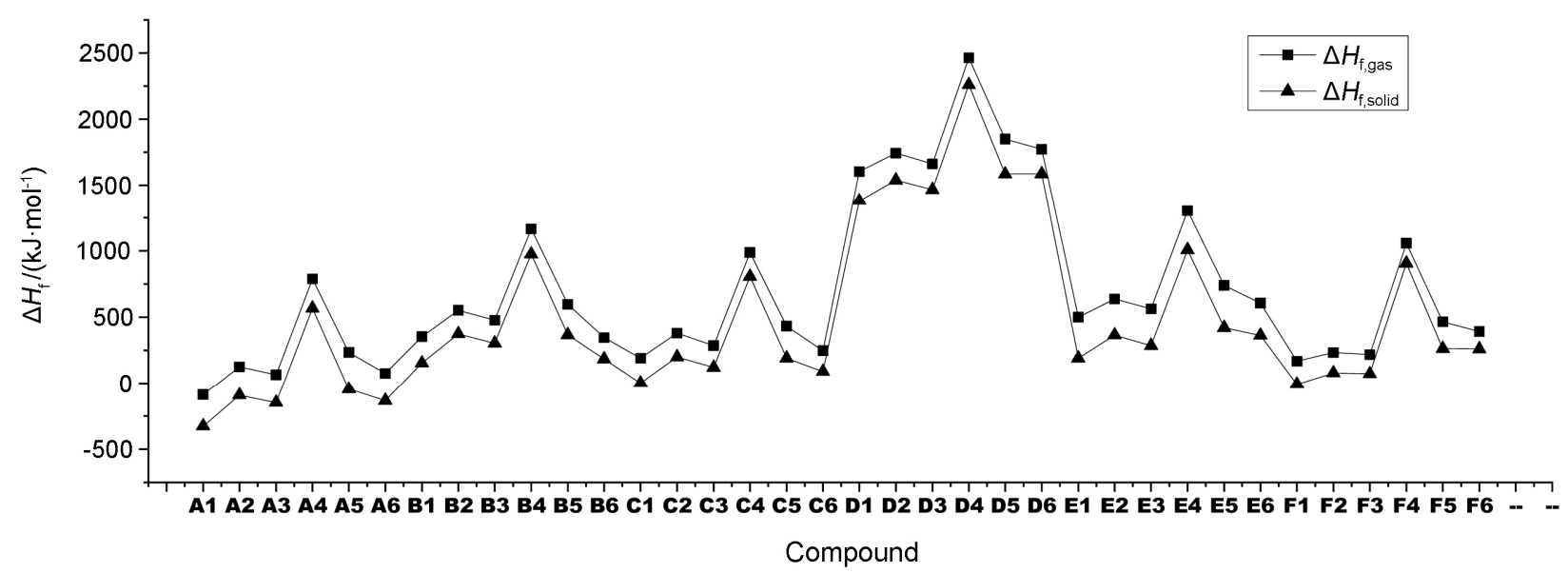

Figure 4 Variation of $\Delta H_{\mathrm{f}, \text { gas }}$ and $\Delta H_{\mathrm{f} \text {,solid }}$ of the title compounds

Table 3 Calculated HOMO and LUMO energies and energy gaps $\left(\Delta E_{\mathrm{LUMO}-\mathrm{HOMO}}\right)$ of the title compounds at $\mathrm{B} 3 \mathrm{LYP} / 6-311++\mathrm{G}(\mathrm{d}, \mathrm{p})$ level

\begin{tabular}{cccc||cccc}
\hline Compd. & $E_{\text {HOMO }} /$ a.u. & $E_{\text {LUMO }} /$ a.u. & $\Delta E_{\text {LUMO-HOMO}} /$ a.u. & Compd. & $E_{\text {HOMO}} /$ a.u. & $E_{\text {LUMO }} /$ a.u. & $\Delta E_{\text {LUMO-HOMO }} /$ a.u. \\
\hline $\mathbf{A}_{\mathbf{1}}$ & -0.2933 & -0.1387 & 0.1546 & $\mathbf{D}_{\mathbf{1}}$ & -0.2617 & -0.1133 & 0.1484 \\
$\mathbf{A}_{\mathbf{2}}$ & -0.3155 & -0.1558 & 0.1597 & $\mathbf{D}_{\mathbf{2}}$ & -0.2760 & -0.1236 & 0.1524 \\
$\mathbf{A}_{\mathbf{3}}$ & -0.3068 & -0.1455 & 0.1613 & $\mathbf{D}_{\mathbf{3}}$ & -0.2668 & -0.0934 & 0.1734 \\
$\mathbf{A}_{\mathbf{4}}$ & -0.2643 & -0.1411 & 0.1232 & $\mathbf{D}_{\mathbf{4}}$ & -0.2440 & -0.0808 & 0.1632 \\
$\mathbf{A}_{\mathbf{5}}$ & -0.282 & -0.1361 & 0.1459 & $\mathbf{D}_{\mathbf{5}}$ & -0.2594 & -0.0883 & 0.1711 \\
$\mathbf{A}_{\mathbf{6}}$ & -0.2386 & -0.1392 & 0.0994 & $\mathbf{D}_{\mathbf{6}}$ & -0.2390 & -0.0727 & 0.1663 \\
$\mathbf{B}_{\mathbf{1}}$ & -0.3327 & -0.1672 & 0.1655 & $\mathbf{E}_{\mathbf{1}}$ & -0.2846 & -0.1126 & 0.1720 \\
$\mathbf{B}_{\mathbf{2}}$ & -0.3453 & -0.1765 & 0.1688 & $\mathbf{E}_{\mathbf{2}}$ & -0.2985 & -0.1360 & 0.1625 \\
$\mathbf{B}_{\mathbf{3}}$ & -0.3389 & -0.1740 & 0.1649 & $\mathbf{E}_{\mathbf{3}}$ & -0.2974 & -0.1074 & 0.1900 \\
$\mathbf{B}_{\mathbf{4}}$ & -0.2981 & -0.1588 & 0.1393 & $\mathbf{E}_{\mathbf{4}}$ & -0.2590 & -0.0964 & 0.1626 \\
$\mathbf{B}_{\mathbf{5}}$ & -0.3145 & -0.1631 & 0.1514 & $\mathbf{E}_{\mathbf{5}}$ & -0.2808 & -0.1006 & 0.1802 \\
$\mathbf{B}_{\mathbf{6}}$ & -0.2783 & -0.1398 & 0.1385 & $\mathbf{E}_{\mathbf{6}}$ & -0.2404 & -0.0898 & 0.1506 \\
$\mathbf{C}_{\mathbf{1}}$ & -0.3210 & -0.1299 & 0.1911 & $\mathbf{F}_{\mathbf{1}}$ & -0.2266 & -0.1031 & 0.1235 \\
$\mathbf{C}_{\mathbf{2}}$ & -0.3342 & -0.1494 & 0.1848 & $\mathbf{F}_{\mathbf{2}}$ & -0.2375 & -0.0930 & 0.1445 \\
$\mathbf{C}_{\mathbf{3}}$ & -0.3380 & -0.1356 & 0.2024 & $\mathbf{F}_{\mathbf{3}}$ & -0.2330 & -0.0478 & 0.1852 \\
$\mathbf{C}_{\mathbf{4}}$ & -0.2840 & -0.1175 & 0.1665 & $\mathbf{F}_{\mathbf{4}}$ & -0.2120 & -0.0477 & 0.1643 \\
$\mathbf{C}_{\mathbf{5}}$ & -0.3118 & -0.1191 & 0.1927 & $\mathbf{F}_{\mathbf{5}}$ & -0.2245 & -0.0645 & 0.1600 \\
$\mathbf{C}_{\mathbf{6}}$ & -0.2621 & -0.0952 & 0.1669 & $\mathbf{F}_{\mathbf{6}}$ & -0.1973 & -0.0222 & 0.1751 \\
\hline
\end{tabular}

$\mathrm{ONO}_{2}, \mathrm{~N}_{3}, \mathrm{~N}\left(\mathrm{NO}_{2}\right) \mathrm{CH}_{3}$ and $\mathrm{NH}_{2}$-substituted compounds would decrease the reactivity, while the grows within a narrow range when the incorporation of $\mathrm{NF}_{2}$ into $\mathrm{NO}_{2}$ substituted compounds. However, the LUMO-HOMO gaps were suggestive of reactivity only as approximation. In all, $\mathbf{C}_{3}$ had the highest value of $\Delta E_{\mathrm{LUMO}-\text {-номо }}$ among the title compounds.

\subsection{Detonation properties}

Table 4 listed the calculated density, molecular and detonation properties and impact sensitivity of the title compounds at B3PW91/6-31G(d,p) level. Figure 6 presented the effects of different substituents on $\rho(\mathrm{a}), D(\mathrm{~b}), P(\mathrm{c})$ and $h_{50}(\mathrm{~d})$ of the title compounds.

The substitution of $\mathrm{NF}_{2}$ increased and had the highest values of $\rho, D$ and $P$ for almost all series of title compounds except for $\mathbf{F}_{\mathbf{3}} . \mathbf{F}_{\mathbf{3}}$ had a little lower value of $\rho$ comparing with $\mathbf{F}_{2}$. This indicated that $\mathrm{NF}_{2}$ group could be the most useful energetic substituents for improving the calculated density and detonation properties of bis(3,4,5-substituted pyrazolyl)methane derivatives. The predicted values of $\rho$, $D, P$ and $h_{50}$ for $\mathbf{B}_{\mathbf{2}}$ and $\mathbf{B}_{\mathbf{6}}$ were close but little lower than the values given in Ref. [33]. The data of $h_{50}$ had a middle fluctuation, and its distribution was not regular.

$\mathbf{C}_{\mathbf{3}}$ had the higher $\rho$ and $D$ than CL-20. But $h_{50}$ of $\mathbf{C}_{\mathbf{3}}$ is too low which indicated its high impact sensitivity. Bis[3,5bis(difluoroamino)-4-nitropyrazolyl]methane $\left(\mathbf{C}_{2}\right)$ had relatively good crystal density $\left(\rho=2.11 \mathrm{~g} / \mathrm{cm}^{3}\right)$ and detonation properties $(D=9.80 \mathrm{~km} / \mathrm{s}, P=46.62 \mathrm{GPa})$ and impact sensitivity $\left(h_{50}, 6.8 \mathrm{~J}\right)$ which showed it could be used as potential energetic material. Meanwhile, the calculated values of $\Delta H_{\mathrm{f}, \text { solid }}$ from Table 2 also showed that $\mathbf{C}_{2}$ was more suitable than $\mathbf{C}_{\mathbf{3}}$ as a potential candidate for high energy density materials. 


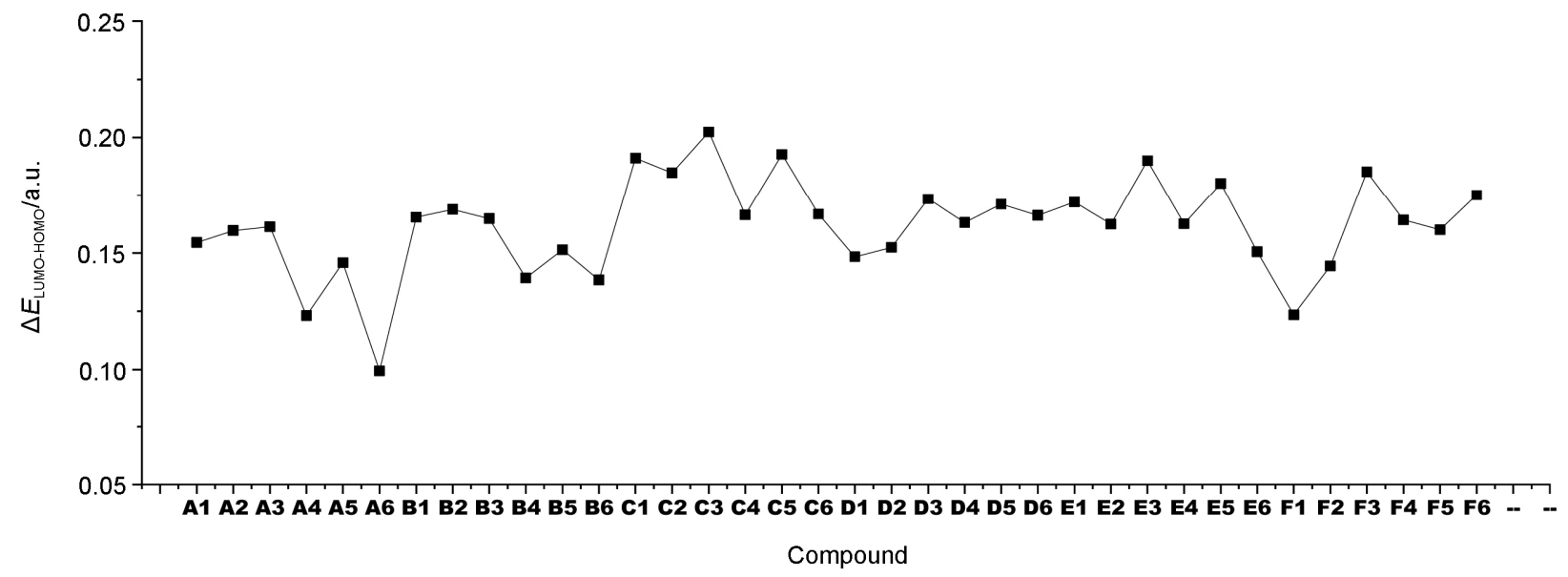

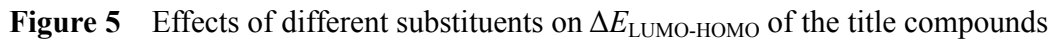

Table 4 Calculated uncorrected density $(M / V(0.001))$, corrected density (crystal density), detonation velocity $(D)$, detonation pressure $(P)$, molecular properties and impact sensitivity $\left(h_{50}\right)$ of the title compounds at B3PW91/6-31G(d,p) level

\begin{tabular}{|c|c|c|c|c|c|c|c|c|c|}
\hline Compd. & $\begin{array}{c}M / V(0.001) \\
\left(\mathrm{g} \cdot \mathrm{cm}^{-3}\right)\end{array}$ & $\begin{array}{c}v \sigma_{\mathrm{tot}}^{2} / \\
\left(\mathrm{kcal} \cdot \mathrm{mol}^{-1}\right)^{2}\end{array}$ & $\begin{array}{c}\text { Crystal density/ } \\
\left(\mathrm{g} \cdot \mathrm{cm}^{-3}\right)\end{array}$ & $\mathrm{Q} /\left(\mathrm{J} \bullet \mathrm{g}^{-1}\right)$ & $D /\left(\mathrm{km} \cdot \mathrm{s}^{-1}\right)$ & $P / G P a$ & $v$ & $\begin{array}{c}\sigma_{+}{ }^{2} / \\
\left(\mathrm{kcal} \cdot \mathrm{mol}^{-1}\right)^{2}\end{array}$ & $h_{50} / \mathrm{J}$ \\
\hline $\mathbf{A}_{1}$ & 2.00 & 10.87 & 1.91 & 1241.5 & 8.56 & 33.63 & 0.07068 & 174.30 & 3.1 \\
\hline $\mathbf{A}_{2}$ & 1.99 & 29.23 & 1.95 & 1440.2 & 9.00 & 37.62 & 0.1544 & 186.33 & 8.0 \\
\hline $\mathbf{A}_{3}$ & 2.06 & 10.96 & 1.97 & 1574.1 & 9.35 & 40.84 & 0.06361 & 197.50 & 2.6 \\
\hline $\mathbf{A}_{4}$ & 1.90 & 12.71 & 1.82 & 1498.8 & 8.60 & 33.06 & 0.1053 & 131.10 & 5.2 \\
\hline $\mathbf{A}_{5}$ & 1.88 & 30.58 & 1.86 & 1452.5 & 8.69 & 34.15 & 0.2069 & 131.76 & 11.2 \\
\hline $\mathbf{A}_{6}$ & 1.86 & 20.95 & 1.81 & 1338.4 & 8.34 & 30.96 & 0.1033 & 224.28 & 4.9 \\
\hline $\mathbf{B}_{1}$ & 1.98 & 22.78 & 1.93 & 1568.7 & 9.07 & 38.04 & 0.1140 & 213.63 & 5.6 \\
\hline $\mathbf{B}_{2}$ & 1.96 & 20.01 & $1.90(1.934)^{a}$ & 1589.6 & $8.91(9.30)^{a}$ & $36.37(39.10)^{a}$ & 0.0708 & 310.49 & $2.9(4.0)^{a}$ \\
\hline $\mathbf{B}_{3}$ & 2.07 & 24.81 & 2.01 & 1621.7 & 9.39 & 41.67 & 0.0948 & 283.11 & 4.3 \\
\hline $\mathbf{B}_{4}$ & 1.89 & 31.46 & 1.87 & 1511.7 & 8.61 & 33.60 & 0.1754 & 171.44 & 9.3 \\
\hline $\mathbf{B}_{5}$ & 1.86 & 28.02 & 1.83 & 1460 & 8.44 & 31.95 & 0.1579 & 173.27 & 8.2 \\
\hline $\mathbf{B}_{6}$ & 1.85 & 33.51 & $1.84(1.80)^{a}$ & 1263.8 & $8.11(8.33)^{a}$ & $29.58(29.60)^{a}$ & 0.1946 & 159.93 & $10.4(11.0)^{a}$ \\
\hline $\mathrm{C}_{1}$ & 2.14 & 9.85 & 2.04 & 1623.1 & 9.63 & 44.20 & 0.06503 & 177.16 & 2.7 \\
\hline $\mathrm{C}_{2}$ & 2.15 & 32.33 & 2.11 & 1635.3 & 9.80 & 46.62 & 0.1355 & 236.97 & 6.8 \\
\hline $\mathrm{C}_{3}$ & 2.24 & 10.84 & 2.13 & 1660.3 & 9.95 & 48.30 & 0.05897 & 214.98 & 2.3 \\
\hline $\mathrm{C}_{4}$ & 2.04 & 14.04 & 1.96 & 1565.1 & 9.08 & 38.44 & 0.1059 & 142.69 & 5.2 \\
\hline $\mathrm{C}_{5}$ & 1.99 & 33.46 & 1.97 & 1505.3 & 9.05 & 38.26 & 0.2098 & 137.07 & 11.4 \\
\hline $\mathrm{C}_{6}$ & 2.01 & 25.08 & 1.96 & 1387 & 8.78 & 35.95 & 0.1162 & 226.53 & 5.7 \\
\hline$D_{1}$ & 1.80 & 16.43 & 1.74 & 1434.4 & 8.08 & 28.36 & 0.1524 & 116.70 & 8.0 \\
\hline $\mathbf{D}_{2}$ & 1.80 & 34.67 & 1.79 & 1409.2 & 8.09 & 28.96 & 0.2329 & 120.00 & 12.7 \\
\hline $\mathbf{D}_{3}$ & 1.87 & 18.02 & 1.81 & 1447.2 & 8.26 & 30.38 & 0.1679 & 107.79 & 8.9 \\
\hline $\mathbf{D}_{4}$ & 1.69 & 17.42 & 1.65 & 1370.7 & 7.60 & 24.30 & 0.1796 & 97.07 & 9.6 \\
\hline $\mathbf{D}_{5}$ & 1.69 & 29.77 & 1.68 & 1325.9 & 7.58 & 24.42 & 0.2488 & 83.07 & 13.7 \\
\hline$D_{6}$ & 1.63 & 35.34 & 1.64 & 1108.3 & 7.36 & 22.68 & 0.2177 & 145.08 & 11.8 \\
\hline $\mathbf{E}_{1}$ & 1.78 & 28.42 & 1.76 & 1376.9 & 8.12 & 28.86 & 0.2039 & 123.07 & 11.0 \\
\hline $\mathbf{E}_{2}$ & 1.77 & 37.35 & 1.77 & 1360.9 & 8.05 & 28.45 & 0.2101 & 146.56 & 11.4 \\
\hline $\mathbf{E}_{3}$ & 1.82 & 35.91 & 1.82 & 1387.7 & 8.28 & 30.60 & 0.2198 & 132.26 & 12.0 \\
\hline $\mathbf{E}_{4}$ & 1.70 & 31.25 & 1.69 & 1315.6 & 7.64 & 24.91 & 0.2350 & 101.70 & 12.9 \\
\hline $\mathbf{E}_{5}$ & 1.71 & 31.10 & 1.70 & 1304.6 & 7.69 & 25.33 & 0.2421 & 94.06 & 13.3 \\
\hline$E_{6}$ & 1.65 & 34.89 & 1.66 & 1158.2 & 7.35 & 22.79 & 0.2305 & 120.05 & 12.6 \\
\hline
\end{tabular}


Continued

\begin{tabular}{|c|c|c|c|c|c|c|c|c|c|}
\hline Compd. & $\begin{array}{c}M / V(0.001) \\
\left(\mathrm{g} \cdot \mathrm{cm}^{-3}\right)\end{array}$ & $\begin{array}{c}v \sigma_{\mathrm{tot}}^{2} / \\
\left(\mathrm{kcal} \cdot \mathrm{mol}^{-1}\right)^{2}\end{array}$ & $\begin{array}{c}\text { Crystal density/ } \\
\left(\mathrm{g} \cdot \mathrm{cm}^{-3}\right)\end{array}$ & $\mathrm{Q} /\left(\mathrm{J} \bullet \mathrm{g}^{-1}\right)$ & $D /\left(\mathrm{km} \cdot \mathrm{s}^{-1}\right)$ & $P / \mathrm{GPa}$ & $v$ & $\begin{array}{c}\sigma_{+}{ }^{2} / \\
\left(\mathrm{kcal} \cdot \mathrm{mol}^{-1}\right)^{2}\end{array}$ & $h_{50} / \mathrm{J}$ \\
\hline $\mathbf{F}_{1}$ & 1.70 & 30.21 & 1.69 & 1012.8 & 7.19 & 22.06 & 0.1717 & 177.81 & 9.0 \\
\hline $\mathbf{F}_{2}$ & 1.69 & 54.42 & 1.75 & 839.1 & 7.01 & 21.44 & 0.2380 & 175.27 & 13.0 \\
\hline $\mathbf{F}_{3}$ & 1.77 & 25.95 & 1.74 & 997.1 & 7.19 & 22.44 & 0.1540 & 183.70 & 8.0 \\
\hline $\mathbf{F}_{4}$ & 1.56 & 30.90 & 1.56 & 746.4 & 6.62 & 17.74 & 0.1886 & 169.15 & 10.0 \\
\hline $\mathbf{F}_{5}$ & 1.58 & 48.53 & 1.63 & 826.2 & 6.87 & 19.68 & 0.2425 & 150.43 & 13.3 \\
\hline $\mathbf{F}_{6}$ & 1.45 & 38.57 & 1.48 & 262.2 & 5.05 & 9.97 & 0.2462 & 122.18 & 13.5 \\
\hline $\mathrm{RDX}^{b}$ & - & - & 1.80 & - & 8.76 & 34.7 & 0.1563 & 200.86 & 8.1 \\
\hline $\mathrm{HMX}^{b}$ & - & - & 1.91 & - & 9.10 & 39.6 & 0.1423 & 189.76 & 7.4 \\
\hline CL- $20^{b}$ & - & - & 2.04 & - & 9.66 & 48.3 & 0.0713 & 333.71 & 2.9 \\
\hline
\end{tabular}

${ }^{a}$ Calculated values taken from Ref. [22]; ${ }^{b}$ Calculated values taken from Ref. [60].
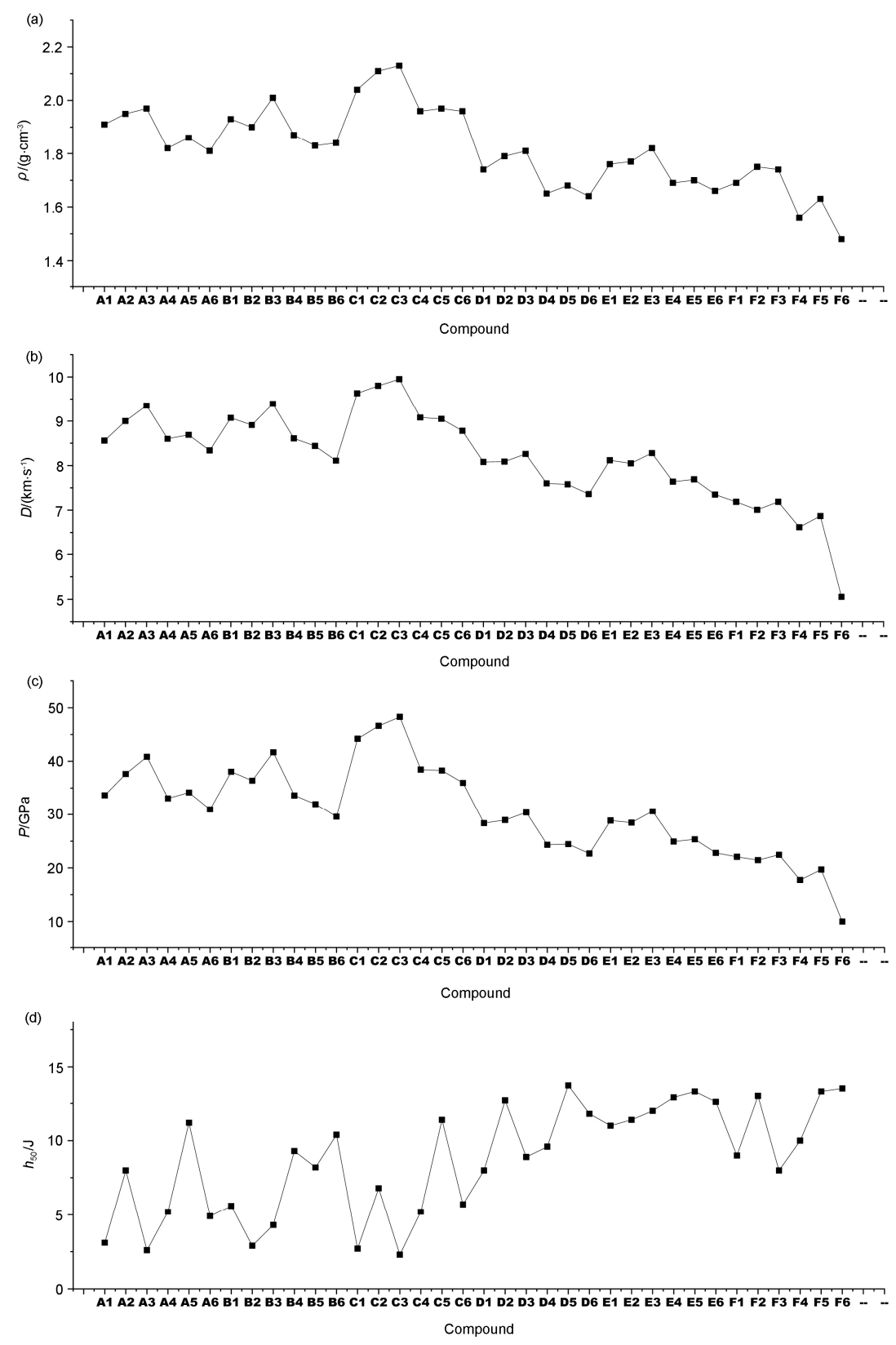

Figure 6 Effects of different substituents on $\rho$ (a), $D(\mathrm{~b}), P(\mathrm{c})$ and $h_{50}(\mathrm{~d})$ of the title compounds 


\subsection{Thermal stability}

Table 5 presented the $\mathrm{BDE}_{\mathrm{ZPE}}$ of relatively weak bonds for the title compounds at B3LYP/6-311+ $+\mathrm{G}(\mathrm{d}, \mathrm{p})$ level. All of the $\mathrm{O}-\mathrm{NO}_{2}$ bonds had the value of $\mathrm{BDE}_{\mathrm{ZPE}}$ under 32 $\mathrm{kJ} / \mathrm{mol}$, which indicated that this energetic group could not be designed and put into the structures of bis(3,4,5substituted pyrazolyl)methane. However, $\mathrm{O}-\mathrm{NO}_{2}$ bonds could be relatively stabilized by $\mathrm{NO}_{2}$ groups and the $\mathrm{O}-\mathrm{NO}_{2}$ bond in $\mathbf{B}_{1}$ had the highest value of $\mathrm{BDE}_{\mathrm{ZPE}}$. The second weakest bond belonged to $\mathrm{N}-\mathrm{NO}_{2}$. These indicated that $\mathrm{ONO}_{2}$ and $\mathrm{N}\left(\mathrm{CH}_{3}\right) \mathrm{NO}_{2}$ groups could not be introduced into this structure. The thermal stability of title compounds decreased in the order: $\mathrm{F}>\mathrm{D}>\mathrm{C}>\mathrm{B}>\mathrm{E}>\mathrm{A}$.

Table 5 Bond dissociation energies $\left(\mathrm{BDE}_{\mathrm{ZPE}}, \mathrm{kJ} \cdot \mathrm{mol}^{-1}\right)$ of the relatively weak bonds for the title compounds at $\mathrm{B} 3 \mathrm{LYP} / 6-311++$ $\mathrm{G}(\mathrm{d}, \mathrm{p})$ level

\begin{tabular}{|c|c|c|c|c|c|c|}
\hline \multirow{2}{*}{ Compound } & \multicolumn{6}{|c|}{$\mathrm{BDE}_{\mathrm{ZPE}}$} \\
\hline & $3-\mathrm{O}-\mathrm{NO}_{2}$ & $3-\mathrm{ONO}_{2}$ or $\mathrm{NX}$ & 5-O-NO $\mathrm{NO}_{2}$ & $5-\mathrm{ONO}_{2}$ or $\mathrm{NX}$ & $4-\mathrm{O}-\mathrm{NO}_{2}$ & $4-\mathrm{ONO}_{2}$ or $4-\mathrm{NX}$ \\
\hline $\mathbf{A}_{1}$ & 11.06 & 345.86 & -113.39 & 357.15 & -114.7 & 356.10 \\
\hline $\mathbf{A}_{2}$ & 26.55 & 345.59 & 1.61 & 357.15 & & 265.21 \\
\hline $\mathbf{A}_{3}$ & 22.35 & 345.59 & -9.15 & 360.04 & & 277.63 \\
\hline $\mathbf{A}_{4}$ & -48.80 & 350.58 & -36.98 & 371.06 & & 351.37 \\
\hline $\mathbf{A}_{5}$ & 4.76 & 346.12 & -20.44 & 357.41 & & -44.34 \\
\hline $\mathbf{A}_{6}$ & -67.97 & 351.63 & -45.39 & 364.5 & & 434.52 \\
\hline $\mathbf{B}_{1}$ & & 234.23 & & 238.69 & 31.28 & 345.59 \\
\hline $\mathbf{B}_{2}$ & & 229.24 & & 226.88 & & 222.94 \\
\hline $\mathbf{B}_{3}$ & & 226.62 & & 216.9 & & 237.98 \\
\hline $\mathbf{B}_{4}$ & & 233.97 & & 239.74 & & 329.06 \\
\hline $\mathbf{B}_{5}$ & & 236.59 & & 235.02 & & 103.74 \\
\hline $\mathbf{B}_{6}$ & & 270.72 & & 262.58 & & 464.19 \\
\hline $\mathrm{C}_{1}$ & & 255.31 & & 262.13 & 17.63 & 350.06 \\
\hline $\mathbf{C}_{2}$ & & 243.49 & & 244.81 & & 231.34 \\
\hline $\mathrm{C}_{3}$ & & 251.11 & & 251.63 & & 260.03 \\
\hline $\mathrm{C}_{4}$ & & 259.77 & & 270.01 & & 345.07 \\
\hline $\mathrm{C}_{5}$ & & 257.15 & & 255.31 & & 84.84 \\
\hline $\mathrm{C}_{6}$ & & 272.64 & & 265.29 & & 435.84 \\
\hline$D_{1}$ & & 334.31 & & 351.11 & -6.27 & 365.29 \\
\hline $\mathbf{D}_{2}$ & & 334.83 & & 347.70 & & 268.89 \\
\hline $\mathbf{D}_{3}$ & & 334.57 & & 350.58 & & 288.91 \\
\hline $\mathbf{D}_{4}$ & & 317.77 & & 332.21 & & 322.49 \\
\hline $\mathbf{D}_{5}$ & & 340.35 & & 345.07 & & 74.34 \\
\hline$D_{6}$ & & 334.31 & & 336.14 & & 388.84 \\
\hline $\mathbf{E}_{1}$ & & 80.64 & & -35.67 & 1.87 & 341.13 \\
\hline $\mathbf{E}_{2}$ & & 91.14 & & 83.26 & & 246.31 \\
\hline $\mathbf{E}_{3}$ & & 83.79 & & 70.92 & & 266.07 \\
\hline $\mathbf{E}_{4}$ & & 73.02 & & 66.98 & & 331.68 \\
\hline $\mathbf{E}_{5}$ & & 80.38 & & 106.10 & & 80.90 \\
\hline $\mathbf{E}_{6}$ & & 72.50 & & 67.25 & & 405.64 \\
\hline $\mathbf{F}_{1}$ & & 419.82 & & 436.89 & -10.99 & 345.59 \\
\hline $\mathbf{F}_{2}$ & & 428.48 & & 448.70 & & 328.22 \\
\hline$F_{3}$ & & 416.93 & & 437.15 & & 317.53 \\
\hline $\mathbf{F}_{4}$ & & 406.43 & & 405.91 & & 334.04 \\
\hline$F_{5}$ & & 395.93 & & 416.93 & & 79.32 \\
\hline$F_{6}$ & & 396.19 & & 422.18 & & 393.83 \\
\hline
\end{tabular}




\section{Conclusions}

The HOFs, energy properties, and thermal stability of a series of bis(3,4,5-substituted pyrazolyl)methane derivatives with different energetic substituents were studied using DFT methods. The azido group significantly increased the HOFs both in gas and solid states. But the difluoroamino group obviously improved the values of crystal density, detonate velocity and detonation pressure. The impact sensitivity had a middle fluctuation, and its distribution was not regular. $\mathrm{ONO}_{2}$ and $\mathrm{N}\left(\mathrm{CH}_{3}\right) \mathrm{NO}_{2}$ were not suitable to be inserted into the structure of bis $(3,4,5-$ substituted pyrazolyl)methane for their real low BDE values. Besides, many the $\mathrm{BDE}_{\mathrm{ZPE}}$ values were above the suggested energy barrier. $\mathbf{C}_{\mathbf{2}}$ was chosen as a potential high energy material for its highest energetic properties and lowest electronic reactivity.

\section{References}

[1] Fried, L. E.; Manaa, M. R.; Pagoria, P. F.; Simpson, R. L. Annu. Rev. Mater. Res. 2001, 31, 291.

[2] Strout, D. L. J. Phys. Chem. A 2004, 108, 10911.

[3] Nguyen, M. T. Coord. Chem. Rev. 2003, 244, 93.

[4] Xu, X. J.; Xiao, H. M.; Ju, X. H.; Gong, X. D.; Zhu, W. H. J. Phys. Chem. A 2006, 110, 5929.

[5] Rice, B. M.; Byrd, E. F. C.; Mattson, W. D. Struct. Bonding (Berlin) 2007, 125, 85 .

[6] Klapötke, T. M. Struct. Bonding (Berlin) 2007, 125, 153.

[7] Benson, F. R. The High Nitrogen Compounds, Wiley-Interscience, New York, 1984.

[8] Huynh, M. H. V.; Hiskey, M. A.; Archuleta, J. G.; Roemer, E. L.; Gilardi, R. Angew Chem., Int. Ed. 2001, 43, 5658.

[9] Zhou, Y.; Long, X. P.; Wang, X.; Shu, Y. J.; Tian, A. M. Chin. J. Energ. Mater. 2006, 14, 315 (in Chinese).

(周阳, 龙新平, 王欣, 舒远杰, 田安民, 含能材料, 2006, 14, 315.)

[10] Lei, Y. P.; Xu, S. L.; Yang, S. Q. Chem. Propell. Polym. Mater. 2007, 5, 1 (in Chinese).

(雷永鹏, 徐松林，阳世清，化学推进剂与高分子材料，2007，5, 1.)

[11] Neutz, J.; Grosshardt, O.; Schaufele, S.; Schuppler, H.; Schweikert, W. Propellants, Explos., Pyrotech. 2003, 28, 181.

[12] Huynh, M. H. V.; Hiskey, M. A.; Hartline, E. L.; Montoya, D. P.; Gilardi, R. Angew. Chem., Int. Ed. 2004, 43, 4924.

[13] Yu, Z. Y.; Chen, B. H.; Yu, J. Y.; Li, W. J. Chin. J. Energ. Mater. 2004, 12, 34 (in Chinese). (鱼志钰，陈保华，鱼江泳，李文杰，含能材料, 2004, 12, 34.)

[14] Qiu, L.; Xiao, H. M.; Zhu, W. H.; Ju, X. H.; Gong, X. D. Chin. J. Chem. 2006, 24, 1538.

[15] Chavez, D. E.; Hiskey, M. A.; Gilardi, R. D. Angew. Chem., Int. Ed. $2000,39,1791$.

[16] Kerth, J.; Lobbecke, S. Propellants, Explos., Pyrotech. 2002, 27, 111.

[17] Zhang, W. Q.; Zhang, J. H.; Deng, M. C.; Qi, X. J.; Nie, F. D.; Zhang, Q. H. Nat. Commun. 2017, 8, 181.

[18] Wang, Y.; Liu, Y. J. Song, S. W.; Yang, Z. J.; Qi, X. J.; Wang, K. C.; Liu, Y.; Zhang, Q. H.; Tian, Y. Nat. Commun. 2018, 9, 2444.

[19] Hervé, G.; Roussel, C.; Graindorge, H. Angew. Chem., Int. Ed. 2010, 49, 3177.

[20] Li, Y. F.; Fan, X. W.; Wang, Z. Y.; Ju, X. H. J. Mol. Struc.: THEOCHEM 2009, 896, 96.

[21] Ravi, P.; Gore, G. M.; Tewari, S. P.; Sikder, A. K. Int. J. Quantum Chem. 2011, 111, 4352 .

[22] Ravi, P.; Gore, G. M.; Sikder, A. K.; Tewari, S. P. Int. J. Quantum
Chem. 2012, 112, 1667.

[23] Ravi, P.; Gore, G. M.; Tewari, S. P.; Sikder, A. K. Mol. Simulat. 2012, 38, 218.

[24] Yin, P.; Parrish, D. A.; Shreeve, J. M. J. Am. Chem. Soc. 2015, 137, 4778.

[25] Ravi, P.; Gore, G. M.; Tewari, S. P.; Sikder, A. K. Propell. Explos. Pyrot. 2012, 37, 52.

[26] Wang, Y. L.; Zhao, F. Q.; Ji, Y. P.; Pan, Q.; Yi, J. H.; An, T.; Wang, W.; Yu, T.; Lu, X. M. J. Anal. Appl. Pyrol. 2012, 98, 231.

[27] Ravi, P.; Gore, G. M.; Venkatesan, V.; Tewari, S. P.; Sikder, A. K. J. Hazard. Mater. 2010, 183, 859.

[28] Yin, P.; Mitchell, L. A.; Parrish, D. A.; Shreeve, J. M. Chem. Asian J. 2017, 12, 378

[29] He, C.; Zhang, J.; Parrish, D. A.; Shreeve, J. M. J. Mater. Chem. A 2013, $1,2863$.

[30] Kumar, D.; Imler, G. H.; Parrish, D. A.; Shreeve, J. M. Chem. Eur. J. 2017, 23, 7876.

[31] Yin, P.; Zhang, J.; Parrish, D. A.; Shreeve, J. M. Chem. Eur. J. 2014, 20, 16529 .

[32] Zhang, Y.; Parrish, D. A.; Shreeve, J. M. J. Mater. Chem. 2012, 22, 12659.

[33] Fischer, D.; Gottfried, J. L.; Klapötke, T. M.; Karaghiosoff, K.; Stierstorfer, J.; Witkowski, T. G. Angew. Chem., Int. Ed. 2016, 55, 16132.

[34] Wu, Q.; Zhu, W. H.; Xiao, H. M. J. Mol. Model. 2013, 19, 2945.

[35] Pan, Y.; Li, J. S.; Cheng, B. B.; Zhu, W. H.; Xiao, H. M. Comput. Theor. Chem. 2012, 992, 110.

[36] Wu, Q.; Pan, Y.; Zhu, W. H.; Xiao, H. M. J. Mol. Model. 2013, 19, 1853.

[37] Lee, C.; Yang, W.; Parr, R. G. Phys. Rev. B: Matter Mater. Phys. 1988, 37, 785.

[38] Frisch, M. J.; Pople, J. A.; Binkley, J. S. J. Chem. Phys. 1984, 80, 3265 .

[39] Frisch, M. J.; Trucks, G. W.; Schlegel, H. B.; Scuseria, G. E.; Robb, M. A.; Cheeseman, J. R.; Scalmani, G.; Barone, V.; Mennucci, B.; Petersson, G. A.; Nakatsuji, H.; Caricato, M.; Li, X.; Hratchian, H. P.; Izmaylov, A. F.; Bloino, J.; Zheng, G.; Sonnenberg, J. L.; Hada, M.; Ehara, M.; Toyota, K.; Fukuda, R.; Hasegawa, J.; Ishida, M.; Nakajima, T.; Honda, Y.; Kitao, O.; Nakai, H.; Vreven, T.; Montgomery, J. A., Jr.; Peralta, J. E.; Ogliaro, F.; Bearpark, M.; Heyd, J. J.; Brothers, E.; Kudin, K. N.; Staroverov, V. N.; Keith, T.; Kobayashi, R.; Normand, J.; Raghavachari, K.; Rendell, A.; Burant, J. C.; Iyengar, S. S.; Tomasi, J.; Cossi, M.; Rega, N.; Millam, J. M.; Klene, M.; Knox, J. E.; Cross, J. B.; Bakken, V.; Adamo, C.; Jaramillo, J.; Gomperts, R.; Stratmann, R. E.; Yazyev, O.; Austin, A. J.; Cammi, R.; Pomelli, C.; Ochterski, J. W.; Martin, R. L.; Morokuma, K.; Zakrzewski, V. G.; Voth, G. A.; Salvador, P.; Dannenberg, J. J.; Dapprich, S.; Daniels, A. D.; Farkas, O.; Foresman, J. B.; Ortiz, J. V.; Cioslowski, J.; Fox, D. J. Gaussian 09, Revision B.01, Gaussian, Inc., Wallingford CT, 2010.

[40] Lu, T.; Chen, F. J. Comput. Chem. 2012, 33, 580

[41] Muthurajan, H.; Sivabalan, R.; Talawar, M. B.; Anniyappan, M.; Venugopalan, S. J. Hazard. Mater. 2006, 133, 30.

[42] Chen, Z. X.; Xiao, J. M.; Xiao, H. M.; Chiu, Y. N. J. Phys. Chem. A 1999, 103, 8062

[43] Ju, X. H.; Li, Y. M.; Xiao, H. M. J. Phys. Chem. A 2005, 109, 934.

[44] Ju, X. H.; Wang, X.; Bei, F. L. J. Comput. Chem. 2005, 26, 1263.

[45] Curtiss, L. A.; Raghavachari, K.; Trucks, G. W.; Pople, J. A. J. Chem. Phys. 1991, 94, 7221.

[46] Curtiss, L. A.; Carpenter, J. E.; Raghavachari, K.; Pople, J. A. J. Chem. Phys. 1992, 96, 9030.

[47] Atkins, P. W. Physical Chemistry, Oxford University Press, Oxford, 1982.

[48] Politzer, P.; Murry, J. S.; Grice, M. E.; DeSalvo, M.; Miller, E. Mol. Phys. 1997, 91, 923.

[49] Politzer, P.; Murry, J. S. Cent. Eur. J. Energy Mater. 2011, 8, 209.

[50] Byrd, E. F. C.; Rice, B. M. J. Phys. Chem. A 2006, 110, 1005.

[51] Kamlet, M. J.; Jacobs, S. T. J. Chem. Phys. 1968, 48, 23. 
[52] Politzer, P.; Martines, J.; Murry, J. S.; Concha, M. C.; Toro-Labbé, A. Mol. Phys. 2009, 107, 2095.

[53] Pospíšil, M.; Vávra, P.; Concha, M. C.; Murry, J. S.; Politzer, P. J. Mol. Model. 2010, 16, 895.

[54] Benson, S. W. Thermochemical Kinetic, 2nd ed., Weily Interscience, New York, 1976.

[55] Mills, I.; Cvitas, T.; Homann, K.; Kallay, N.; Kuchitsu, K. Quantities, Units, and Symbols in Physical Chemistry, Blackwell Scien- tific Publications, Oxford, 1988

[56] Blanksby, S. J.; Ellison, G. B. Acc. Chem. Res. 2003, 36, 255.

[57] Scott, A. P.; Radom, L. J. Phys. Chem. 1996, 100, 16502.

[58] Dean, J. A. LANGE's Handbook of Chemistry, 15th ed., Chapter 6, McGraw-Hill Book Co., New York, 1999.

[59] Dean, J. A. LANGE's Handbook of Chemistry, 13th ed., Chapter 9, McGraw-Hill Book Co., New York, 1985.

[60] Shen, C.; Wang, P.; Lu, M. J. Phys. Chem. A 2015, 119, 8250.

(Cheng, F.) 